\title{
Comparative study between intracytoplasmic morphologically selected sperm injection versus intracytoplasmic sperm injection in patients with severe male factor infertility and repeated intra cytoplasmic sperm injection failure
}

\section{Yasser Ibrahim Orief ${ }^{1,2}$, Mohamed Morad Elabd ${ }^{1}$, Tamer Hanafy Mahmoud Said ${ }^{1,2} *$, Nesma Ahmed Abn Jad Ahmed ${ }^{1}$}

\footnotetext{
${ }^{1}$ Department of Obstetrics \& Gynaecology, Faculty of Medicine, Alexandria University, Egypt

${ }^{2}$ Agial fertility Center, Alexandria, Egypt
}

Received: 29 January 2016

Accepted: 01 March 2016

\section{*Correspondence:}

Dr. Tamer Hanafy Mahmoud Said,

E-mail: tamerhanafy74@gmail.com

Copyright: () the author(s), publisher and licensee Medip Academy. This is an open-access article distributed under the terms of the Creative Commons Attribution Non-Commercial License, which permits unrestricted non-commercial use, distribution, and reproduction in any medium, provided the original work is properly cited.

\begin{abstract}
Background: The aim and objective of the study was to compare the results of IMSI and ICSI among infertile couples with severe male factor and repeated ICSI failure.

Methods: A comparative prospective randomized controlled study was carried out in Agial IVF/ICSI center, Alexandria with sample of one hundred and forty infertile couples with severe male factor and repeated ICSI failure using ICSI or IMSI with controlled ovarian hyper-stimulation. The main outcome measures were the chemical and clinical pregnancy rates.

Results: The couples were randomly subdivided equally into two groups: A, B, 70 underwent intra cytoplasmic morphologically selected sperm injection (IMSI) (group A) and 70 underwent intra cytoplasmic sperm injection (ICSI) (group B) treatment. In the IMSI group there were $19(27.14 \%)$ women got pregnant and $51(72.86 \%)$ did not got pregnant, while in the ICSI group, there were 14 (20.0\%) got pregnant and $56(80.0 \%)$ did not got pregnant. Using Pearson Chi-Square test there was no significant difference regarding chemical or clinical pregnancy between the two studied groups.

Conclusions: The use of IMSI was proved to be of no evident role in improvement of outcome of pregnancy rate in infertile couples with severe male factor and repeated ICSI failure, as analyzed data didn't show any significant difference.
\end{abstract}

Keywords: IMSI, ICSI

\section{INTRODUCTION}

Implantation failure is the major cause negatively influencing the outcome of assisted reproductive technologies (ART), as only two out of every ten embryos successfully implant. ${ }^{1}$

The outcome of intra cytoplasmic sperm injection (ICSI) has been shown to be positively associated with the morphological state of the sperm, while early miscarriage rates were negatively associated with nuclear morphology. ${ }^{2,3}$ However, repeated failure of conventional IVF has been suggested to be caused by a paternal effect on early embryo development, a hypothesis confirmed using a shared oocyte donation model. ${ }^{4}$

Bartoov et al developed a method of human spermatozoa evaluation performed in real-time at high magnification called "motile sperm organelle morphology examination" (MSOME). ${ }^{5,6}$ MSOME is performed using an inverted 
microscope equipped with Normarsk interference contrast optics, which enables observation at high magnification (> 6000x) compared to the 200-400x observed by conventional ICSI. ${ }^{6}$ This method led to the development of the intra cytoplasmic morphologically selected sperm injection (IMSI) procedure, which is based on sperm normality as defined by MSOME classification and aims to improve conventional ICSI outcomes by focusing on the correlation between abnormalities in sperm morphology observed at high magnification and DNA damage. ${ }^{7,8}$ Various studies have demonstrated that IMSI significantly improves fertilization rates, embryo quality, the rate of development up to the blastocyst stage, the rates of implantation and pregnancy after embryo transfer on day 2 or 3 or in the blastocyst stage and the likelihood of having a normal healthy child; IMSI also appears to significantly decrease miscarriage rates. ${ }^{2,5,8-11,13}$ In fact, prior failures in ICSI cycles constituted an inclusion criterion in several studies employing IMSI. ${ }^{3,14}$ Various studies have demonstrated that IMSI not significantly improves fertilization rates, implantation and pregnancy rates. ${ }^{15-17}$ To better comprehend the value of IMSI, the purpose of this study was to compare laboratory and clinical outcomes of IMSI versus conventional ICSI in couples with severe male factor and repeated ICSI failures.

The aim and objective of the study was to compare the results of IMSI and ICSI among infertile couples with severe male factor and repeated ICSI failure in terms of: The number of embryos, embryo grading fertilization rate, implantation rate and pregnancy rate which will be diagnosed by: Serum B-HCG assay 14 days after embryo transfer and Clinical pregnancy will be confirmed by observing fetal cardiac pulsations 2 weeks after positive pregnancy test by trans-vaginal ultrasonography (TVS).

\section{METHODS}

\section{Study setting \& design}

This was a comparative prospective randomized controlled study was carried out in Agial IVF/ICSI center, Alexandria, Egypt.

\section{Target population}

(140) Infertile couples signed an informed written consent to declare their agreement to be enrolled in the study as agreed upon by the ethical committee.

All underwent ICSI and IMSI due to severe male factor and repeated ICSI failure from June 2014 to February 2015. The couples were randomly subdivided equally into two groups:

- Group A: 70 cases with previous failed ICSI underwent IMSI.
- Group B: 70 cases with previous failed ICSI underwent ICSI.

Female partners of all couples included in the study were selected according to these criteria:

Inclusion criteria: Age below 37 years, primary or secondary infertility, having good ovarian reserve (AMH $>1.5, \mathrm{AFC}>5$ and basal $\mathrm{FSH}<10 \mathrm{mIu} / \mathrm{L}$ ) and all with at least one previous failed ICSI.

Exclusion criteria: endocrine disorders associated other medical conditions (hypertension, diabetes), abnormal uterine factor diagnosed by vaginal sonography, Hysteroscopy, Hysterosalpingography or previous uterine surgery and stage IV endometrioses or previous ovarian surgery.

Male partners of all couples included in the study were selected according to these criteria:

Inclusion criteria: Severe oligospermia sperm concentration $<5\left(10^{6}\right.$ per $\left.\mathrm{ml}\right)$ and severe teratospermia normal forms $<4 \%$.

Exclusion criteria: Cases with TESE (testicular epididimal sperm extraction).

\section{The ovarian stimulation}

The long down-regulation protocol was used in all patients as (Decapeptyl®, Ferring) a daily subcutaneous dose of $0.1 \mathrm{mg}$ was started on cycle day 21 . On the first day of the new cycle, the serum estradiol was measured. Once a serum estradiol concentration was suppressed to $\leq$ $50 \mathrm{pg} / \mathrm{ml}$, the dose was reduced to $0.05 \mathrm{mg}$ and continued until the day of HCG administration. Ovarian stimulation with recombinant FSH (Gonal F®, Serono) $150 \mathrm{IU}$ as well as urinary human menopausal gonadotropin (uHMG) (Merional®, IBSA) 75 IU began following pituitary down-regulation. The standard initial dose was at least $225 \mathrm{Iu}$ /day of recombinant FSH (Gonal F®, Serono) to be adjusted according to patient previous history, ovarian reserve, age and response during the course of treatment.

The ovarian response was monitored by serial serum estradiol concentrations and trans-vaginal ultrasound beginning on day 5 of stimulation until the day of HCG administration. Based on these results, the FSH/HMG dose and subsequent monitoring were individualized. Ovarian stimulation was continued until at least three follicles reach a mean diameter of $\geq 20 \mathrm{~mm}$, at which time HCG (Choriomon®, IBSA) 10,000 IU s.c. or i.m. was administered 36 hour before oocyte retrieval.

Following oocyte retrieval, the patients received luteal phase support in the form of natural progesterone vaginally in a dose of $600 \mathrm{mg} /$ day (Prontogest Supp ${ }^{\circledR}$, Marcyrl) to continue preparing the endometrium. 


\section{ICSI and IMSI procedures}

After oocyte retrieval, the cumulus and corona radiata were removed mechanically under a stereomicroscope, after exposure to $80 \mathrm{IU} / \mathrm{ml}$ hyalouronidase solution for 30 seconds. Conventional ICSI was done to mature (M II) oocytes with the use of a Hoffman contrast Nikon inverted microscope. Motile normal-looking spermatozoa were selected at x200 magnification to be injected into a mature oocyte. In the IMSI technique, a spermatozoa preselection step was performed at x10, 000 magnification with the use of a Nomarski-contrast Nikon inverted microscope equipped with an x1, 000 magnification oil immersion lens associated with a video camera. This optical system required the use of a glassbottomed dish (Willco GWST $0.17 \mathrm{~mm}$; JCD). An elongated polyvinylpyrrolidone (JCD) 2-mL drop was placed in this dish, covered with an adequate volume of sterile mineral oil (Nidoil; Nidacon International) and inseminated with an adequate amount of selected spermatozoa. Motile spermatozoa for further injection into oocytes were selected under high magnification according to the Vanderzwalmen classification, and transferred into the dish used for classic ICSI procedure before being injected. ${ }^{18}$ Briefly, the primary objective was to select spermatozoa displaying a normal oval head shape without vacuoles or with fewer than two vacuoles representing $<4 \%$ of the head area (grade 1 or 2 ) as well as absence of both cytoplasmic extrusion and tail defects. If not available, the second-best spermatozoa with the least number of vacuoles and/or other abnormalities (grade 3 or 4 ) were selected for injection. ${ }^{18}$ Injected oocytes were incubated in appropriate embryo culture media at $37^{\circ} \mathrm{C}$ under $6 \% \mathrm{CO}_{2}$ humidified atmosphere and observed every day, followed by transfer of embryos in the appropriate time.

\section{Assessment of fertilization and cleavage}

- Oocytes were examined for fertilization 16-18 h after ICSI or IMSI.

- Cleavage of the oocytes was assessed on day 2 (48 h) and day $3(72 \mathrm{~h})$ day 5 (blastocyst) before transfer into the uterus.

The embryos were graded on a scale of 1 to $5 .{ }^{19}$

\section{The gardener blastocyst grading scale $e^{20}$}

The expansion grade scale ranges from 1 (least expanded) to 6 (completely hatched).

The day of embryo transfer was day 3 in all cases of both groups except 7 cases in IMSI group and 2 cases in ICSI group were day 5 .

B-HCG was measured for diagnosis of pregnancy 14 days after embryo transfer and then was measured serially to monitor the rise in its titre. Implantation was noted later by appearance of the gestational sac in the uterus using TVS.

\section{RESULTS}

Table 1: Demographic data.

\begin{tabular}{|c|c|c|c|}
\hline $\begin{array}{l}\text { Test of } \\
\text { significance } \\
\text { (p value) }\end{array}$ & $\begin{array}{l}\text { ICSI } \\
\text { group } \\
(\text { group B) } \\
(n=70)\end{array}$ & $\begin{array}{l}\text { IMSI } \\
\text { group } \\
(\text { group A) } \\
(\mathbf{n}=70)\end{array}$ & \\
\hline $\begin{array}{l}t=0.355 \\
p=0.723 \\
N S\end{array}$ & $\begin{array}{l}24-43 \\
34.99 \pm \\
4.541\end{array}$ & $\begin{array}{l}24-42 \\
34.71 \pm \\
4.508\end{array}$ & $\begin{array}{l}\text { Female age } \\
\text { Min-Max } \\
\text { Mean } \pm \text { S.D. }\end{array}$ \\
\hline $\begin{array}{l}\mathrm{t}=0.356 \\
\mathrm{p}=0.723 \\
\mathrm{NS}\end{array}$ & $\begin{array}{l}28-56 \\
41.24 \pm \\
5.854\end{array}$ & $\begin{array}{l}29-60 \\
40.90 \pm \\
5.549\end{array}$ & $\begin{array}{l}\text { Male age } \\
\text { Min-Max } \\
\text { Mean } \pm \text { S.D. }\end{array}$ \\
\hline $\begin{array}{l}\mathrm{t}=4.288 \\
\mathrm{p}=0.000 *\end{array}$ & $\begin{array}{l}0-5 \\
0.93 \pm \\
1.108\end{array}$ & $\begin{array}{l}0-4 \\
0.24 \pm \\
0.751\end{array}$ & $\begin{array}{l}\text { Gravidity } \\
\text { Min-Max } \\
\text { Mean } \pm \pm \\
\text { S.D. }\end{array}$ \\
\hline $\begin{array}{l}\mathrm{t}=1.481 \\
\mathrm{p}=0.141 \\
\mathrm{NS}\end{array}$ & $\begin{array}{l}0-2 \\
0.27 \pm \\
0.536\end{array}$ & $\begin{array}{l}0-3 \\
0.14 \pm \\
0.490\end{array}$ & $\begin{array}{l}\text { Parity } \\
\text { Min-Max } \\
\text { Mean } \pm \text { S.D. }\end{array}$ \\
\hline
\end{tabular}

NS: Not significant $(p>0.05) ; *$ Significant $(p<0.05)$

Our study demonstrated that, there were no statistical significant differences between the two studied groups regarding demographic data (age, parity) but demonstrated that, there was statistical significant differences regarding the gravidity which in the IMSI group was significantly lower when compared with the ICSI group Table 1, there were no statistical significant differences between the two studied groups regarding laboratory data (number of ampoules, number of stimulation days, estrogen level at HCG day, progesterone level at HCG day, endometrial thickness, number of oocyte retrieved, number of metaphase 1 oocyte, number of metaphase 2 oocyte, number of germinal vesicles, number of fractured oocytes) Table 2, there were no statistical significant differences between the two studied groups regarding (number of class $\mathrm{A}$ embryos, number of embryo transferred, number of blastocyst transferred) but demonstrated that, there were statistical significant differences regarding (number of cleaved cells and number of class B embryos) Table 3, there were no statistical significant differences between the two studied groups regarding fertilization rate, implantation rate and chemical or clinical pregnancy Table 4, 5 and 6.

\section{DISCUSSION}

Currently, ICSI is performed after morphological selection of spermatozoa at 200x to 400x magnification. In this magnification range, spermatozoa carrying defects of the head, neck or tail can be detected, but not nuclear vacuoles. Therefore, magnification of $6000 \mathrm{x}$ to $12,500 \mathrm{x}$ to select spermatozoa, particularly by virtue of permitting a perfect identification of vacuoles, appears to be a better strategy. ${ }^{21}$ 
Table 2: Laboratory data.

\begin{tabular}{|c|c|c|c|}
\hline $\begin{array}{l}\text { Test of significance } \\
\text { (p value) }\end{array}$ & $\begin{array}{l}\text { ICSI group (group B) } \\
(\mathrm{n}=70)\end{array}$ & $\begin{array}{l}\text { IMSI group (group A) } \\
(n=70)\end{array}$ & \\
\hline $\begin{array}{l}t=0.181 \\
p=0.857 \mathrm{NS}\end{array}$ & $\begin{array}{l}33-134 \\
69.92 \pm 17.626\end{array}$ & $\begin{array}{l}28-181 \\
70.58 \pm 24.733\end{array}$ & $\begin{array}{l}\text { Number of ampoules } \\
\text { Min-Max } \\
\text { Mean } \pm \text { S.D. }\end{array}$ \\
\hline $\begin{array}{l}t=1.041 \\
p=0.300 \mathrm{NS}\end{array}$ & $\begin{array}{l}9-18 \\
13.47 \pm 1.988\end{array}$ & $\begin{array}{l}9-18 \\
13.81 \pm 1.898\end{array}$ & $\begin{array}{l}\text { Number of stimulation days } \\
\text { Min-Max } \\
\text { Mean } \pm \text { S.D. }\end{array}$ \\
\hline $\begin{array}{l}\mathrm{t}=3.273 \\
\mathrm{p}=0.001 *\end{array}$ & $\begin{array}{l}816.0-9961.0 \\
3617.17 \pm 1922.543\end{array}$ & $\begin{array}{l}885.0-161400.0 \\
4890.28 \pm 2625.769\end{array}$ & $\begin{array}{l}\text { Estrogen level at hCG day } \\
\text { Min-Max } \\
\text { Mean } \pm \text { S.D. }\end{array}$ \\
\hline $\begin{array}{l}\mathrm{t}=0.142 \\
\mathrm{p}=0.888 \mathrm{NS}\end{array}$ & $\begin{array}{l}0.20-3.25 \\
1.08 \pm 0.644\end{array}$ & $\begin{array}{l}0.18-4.98 \\
1.1 \pm 0.858\end{array}$ & $\begin{array}{l}\text { Progesterone level at hCG day } \\
\text { Min-Max } \\
\text { Mean } \pm \text { S.D. }\end{array}$ \\
\hline $\begin{array}{l}t=1.169 \\
p=0.244 \mathrm{NS}\end{array}$ & $\begin{array}{l}5.0-16.0 \\
10.37 \pm 1.935\end{array}$ & $\begin{array}{l}7.5-17.00 \\
10.73 \pm 1.715\end{array}$ & $\begin{array}{l}\text { Endometrial thickness } \\
\text { Min-Max } \\
\text { Mean } \pm \text { S.D. }\end{array}$ \\
\hline $\begin{array}{l}\mathrm{t}=2.543 \\
\mathrm{p}=0.012 *\end{array}$ & $\begin{array}{l}1-26 \\
11.18 \pm 5.796\end{array}$ & $\begin{array}{l}2-37 \\
14.02 \pm 7.340\end{array}$ & $\begin{array}{l}\text { Number of oocyte retrieved } \\
\text { Min-Max } \\
\text { Mean } \pm \text { S.D. }\end{array}$ \\
\hline $\begin{array}{l}t=2.746 \\
p=0.007 *\end{array}$ & $\begin{array}{l}0-4 \\
0.42 \pm 0.826\end{array}$ & $\begin{array}{l}0-3 \\
0.80 \pm 0.722\end{array}$ & $\begin{array}{l}\text { Number of metaphase } 1 \\
\text { Min-Max } \\
\text { Mean } \pm \text { S.D. }\end{array}$ \\
\hline $\begin{array}{l}\mathrm{t}=2.537 \\
\mathrm{p}=0.012 *\end{array}$ & $\begin{array}{l}1-23 \\
9.52 \pm 5.235\end{array}$ & $\begin{array}{l}2-37 \\
12.22 \pm 7.203\end{array}$ & $\begin{array}{l}\text { Number of metaphase } 2 \\
\text { Min-Max } \\
\text { Mean } \pm \text { S.D. }\end{array}$ \\
\hline $\begin{array}{l}t=1.607 \\
p=0.110 \mathrm{NS}\end{array}$ & $\begin{array}{l}0-5 \\
0.45 \pm 0.927\end{array}$ & $\begin{array}{l}0-5 \\
0.71 \pm 0.965\end{array}$ & $\begin{array}{l}\text { Number of germinal vesicles } \\
\text { Min-Max } \\
\text { Mean } \pm \text { S.D. }\end{array}$ \\
\hline $\begin{array}{l}\mathrm{t}=1.319 \\
\mathrm{p}=0.190 \mathrm{NS}\end{array}$ & $\begin{array}{l}0-4 \\
0.62 \pm 0.965\end{array}$ & $\begin{array}{l}0-7 \\
0.40 \pm 1.082\end{array}$ & $\begin{array}{l}\text { Number of fractured oocytes } \\
\text { Min-Max } \\
\text { Mean } \pm \text { S.D. }\end{array}$ \\
\hline
\end{tabular}

NS: Not significant ( $>0.05) ; *$ Significant $(\mathrm{p}<0.05)$

Table 3: Number of cleaved cells, number of class A embryos, and number of class B embryos, number of embryo transferred, number of blastocyst transferred in the two studied groups.

\begin{tabular}{|c|c|c|c|}
\hline $\begin{array}{l}\text { Test of significance } \\
\text { (p value) }\end{array}$ & $\begin{array}{l}\text { ICSI group (group B) } \\
(\mathrm{n}=70)\end{array}$ & IMSI group (group A) $(\mathrm{n}=70)$ & \\
\hline $\begin{array}{l}\mathrm{t}=2.659 \\
\mathrm{p}=009 *\end{array}$ & $\begin{array}{l}1-20 \\
6.11 \pm 4.130\end{array}$ & $\begin{array}{l}1-30 \\
8.34 \pm 5.666\end{array}$ & $\begin{array}{l}\text { Number of cleaved cells } \\
\text { Min-Max } \\
\text { Mean } \pm \text { S.D. }\end{array}$ \\
\hline $\begin{array}{l}t=1.181 \\
p=240 \mathrm{NS}\end{array}$ & $\begin{array}{l}0-18 \\
5.34 \pm 3.866\end{array}$ & $\begin{array}{l}0-20 \\
6.10 \pm 3.718\end{array}$ & $\begin{array}{l}\text { Number of class A embryos } \\
\text { Min-Max } \\
\text { Mean } \pm \text { S.D. }\end{array}$ \\
\hline $\begin{array}{l}4.292 \\
0.006 *\end{array}$ & $\begin{array}{l}0-6 \\
0.52 \pm 1.176\end{array}$ & $\begin{array}{l}0-15 \\
2.21 \pm 3.068\end{array}$ & $\begin{array}{l}\text { Number of class B embryos } \\
\text { Min-Max } \\
\text { Mean } \pm \text { S.D. }\end{array}$ \\
\hline $\begin{array}{l}1.731 \\
0.086 \mathrm{NS}\end{array}$ & $\begin{array}{l}1-7 \\
4.27 \pm 1.632\end{array}$ & $\begin{array}{l}1-7 \\
4.71 \pm 1.384\end{array}$ & $\begin{array}{l}\text { Number of embryo transferred } \\
\text { Min-Max } \\
\text { Mean } \pm \text { S.D. }\end{array}$ \\
\hline $\begin{array}{l}X^{2}{ }_{\text {(Yates) }}=1.90 \\
p=0.168 \mathrm{NS}\end{array}$ & $2(2.9 \%)$ & $7(10.0 \%)$ & $\begin{array}{l}\text { Number of blastocyst } \\
\text { transferred } n(\%)\end{array}$ \\
\hline
\end{tabular}

NS: Not significant $(\mathrm{p}>0.05) ; *$ Significant $(\mathrm{p}<0.05)$ 
Table 4: Fertilization rate in the two studied groups.

\begin{tabular}{|l|l|l|}
\hline $\begin{array}{l}\text { ICSI group } \\
(\text { group B })(\mathbf{n = 7 0})\end{array}$ & $\begin{array}{l}\text { IMSI group } \\
(\text { group A })(\mathbf{n = 7 0})\end{array}$ & \\
\hline 7.69 & 12.50 & Min \\
\hline 100.00 & 100.00 & Max \\
\hline 56.13 & 58.7905 & Mean \\
\hline 24.08 & 20.48291 & S.D. \\
\hline 0.704 & & t-test \\
$0.483 \mathrm{NS}$ & & p value \\
\hline
\end{tabular}

NS: Not significant $(\mathrm{p}>0.05)$

Table 5: Implantation rate in the two studied groups.

\begin{tabular}{|l|l|l|}
\hline $\begin{array}{l}\text { ICSI group } \\
(\text { group B })(\mathbf{n = 7 0})\end{array}$ & $\begin{array}{l}\text { IMSI group } \\
(\text { group A })(\mathbf{n = 7 0})\end{array}$ & Min \\
\hline 6.59 & 11.30 & Max \\
\hline 100.00 & 100.00 & Mean \\
\hline 53.11 & 56.6915 & S.D. \\
\hline 22.13 & 19.38281 & t-test \\
\hline 1.019 & & p value \\
$0.310 \mathrm{NS}$ & & \\
\hline
\end{tabular}

NS: Not significant $(\mathrm{p}>0.05)$

Table 6: Number of chemical or clinical pregnancy in the two studied groups.

\begin{tabular}{|c|c|c|}
\hline \multicolumn{2}{|l|}{ Group } & \\
\hline $\begin{array}{l}\text { ICSI group } \\
(\mathrm{n}, \%)\end{array}$ & $\begin{array}{l}\text { IMSI group } \\
(\mathrm{n}, \%)\end{array}$ & \\
\hline $14(20.0 \%)$ & $19(27.14 \%)$ & Pregnancy \\
\hline $56(80.0 \%)$ & $51(72.86 \%)$ & No-pregnancy \\
\hline $70(100 \%)$ & $70(100 \%)$ & Total \\
\hline
\end{tabular}

$\mathrm{X}^{2}=0.991 ; \mathrm{p}=0.319 \mathrm{NS}$

Our study demonstrated that, there were no statistical significant differences between the two studied groups regarding fertilization rate, implantation rate and chemical or clinical pregnancy.

Our study agree with Balaban et al, Oliveira et al, Marci et al and Borges Jr et al who conducted a prospective randomized studies and reported no statistically significant differences between the two groups were observed with regard to rates of fertilization, implantation and pregnancy/cycle..$^{10,15-17}$

But our study not agree with Teixeira et al who reported that IMSI was associated with a significant improvement in clinical pregnancy rate (RR $1.29,95 \%$ CI 1.07 to 1.56 , 9 RCTs, 2014 women, I2 $=57 \%$, very-low-quality evidence). ${ }^{22}$ Bartoov et al reported that pregnancy rate after modified ICSI was significantly higher than that of the routine ICSI procedure $(66.0 \%$ vs. $30.0 \%) .{ }^{5}$ Berkovitz et al confirmed that the selection and the subsequent injection of spermatozoa with normal nuclear morphology reduced the risk of major fetal malformations. ${ }^{12}$ Setti et al reported similar clinical outcomes in couples undergoing either IMSI or ICSI, except that a significantly higher fertilization rate was observed in the former procedure. ${ }^{23} \mathrm{Knez}$ et al reported that The IMSI group was characterized by a higher number of blastocysts per cycle than the ICSI group $(0.80$ vs. 0.65$)$ after a prolonged 5-day embryo culture with a tendency toward higher implantation and pregnancy rates per cycle was achieved in the IMSI group compared to the ICSI group $(17.1 \%$ vs. $6.8 \% ; 25.0 \%$ vs. $8.1 \%$, respectively). ${ }^{24}$ Kim et al reported that no significant difference in the fertilization rate between IMSI and previous ICSI cycles $(67.7 \%$ vs. $65.0 \%){ }^{25}$ However, the pregnancy and implantation rates with IMSI were significantly higher than those of the ICSI cycles $(33.3 \%$ vs. $12.5 \%$ and $14.6 \%$ vs. $5.4 \%$, respectively; $\mathrm{p}<0.05)$.

\section{CONCLUSIONS}

The use of IMSI was proved to be of no evident role in improvement of outcome of pregnancy rate in infertile couples with severe male factor and repeated ICSI failure, as analysed data didn't show any significant difference.

\section{Recommendation}

More efforts are needed to be done to find effective procedures to improve pregnancy rate in such cases. Further studies are needed to be conducted on a wider scale and to be applied on larger number of cases.

\section{Funding: Not required}

Conflict of interest: None declared

Ethical approval: The study was approved by the Institutional Ethics Committee

\section{REFERENCES}

1. Seli E, Vergouw CG, Morita H, Botros L, Roos P, Lambalk $\mathrm{CB}$, et al. Noninvasive metabolomic profiling as an adjunct to morphology for noninvasive embryo assessment in women undergoing single embryo transfer. Fertil Steril. 2010;94:535-42.

2. Berkovitz A, Eltes F, Ellenbogen A, Peer S, Feldberg D, Bartoov B. Does the presence of nuclear vacuoles in human sperm selected for ICSI affect pregnancy outcome? Hum Reprod. 2006;21:1787-90.

3. Berkovitz A, Eltes F, Yaari S, Katz N, Barr I, Fishman A, et al. The morphological normalcy of the sperm nucleus and pregnancy rate of intracytoplasmic injection with morphologically selected sperm. Hum Reprod. 2005;20:185-90.

4. Hazout A, Dumont-Hassan M, Junca AM, Cohen Bacrie P, Tesarik J. High magnification ICSI overcomes paternal effect resistant to conventional ICSI. Reprod Biomed Online. 2006;12:19-25.

5. Bartoov B, Berkovitz A, Eltes F, Kogosovsky A, Yagoda A, Lederman $\mathrm{H}$, et al. Pregnancy rates are higher with intracytoplasmic morphologically selected sperm injection than with conventional 
intracytoplasmic injection. Fertil Steril. 2003;80:1413-9.

6. Bartoov B, Berkovitz A, Eltes F, Kogosowski A, Menezo Y, Barak Y. Real-time fine morphology of motile human sperm cells is associated with IVFICSI outcome. J Androl. 2002;23:1-8.

7. Oliveira JB, Massaro FC, Baruffi RL, Mauri AL, Petersen CG, Silva LF, et al. Correlation between semen analysis by motile sperm organelle morphology examination and sperm DNA damage. Fertil Steril. 2010;94:1937-40.

8. Wilding M, Coppola G, di Matteo L, Palagiano A, Fusco E, Dale B. Intracytoplasmic injection of morphologically selected spermatozoa (IMSI) improves outcome after assisted reproduction by deselecting physiologically poor quality spermatozoa. J Assist Reprod Genet. 2011;28:25362.

9. Yazbeck C, Delaroche L, Jacquesson L, Ayel JP, Selva J, Rougier N. Intracytoplasmic morphologically selected sperm injection (IMSI): is it a good choice after two or more IVF or ICSI failures? Fertil Steril. 2008;90:S416.

10. Balaban B, Yakin K, Alatas C, Oktem O, Isiklar A, Urman B. Clinical outcome of intracytoplasmic injection of spermatozoa morphologically selected under high magnification: a prospective randomized study. Reprod Biomed Online. 2011;22(5):472-6.

11. Tasaka A, Doshida M, Sato Y, Kyoya T, Nakajo Y, Kyono K. Outcome of IMSI (intracytoplasmic morphologically selected sperm injection) in patients with repeated ICSI failures. Fertil Steril. 2009;92(3):S76.

12. Berkovitz A, Eltes F, Paul M, Adrian E, Bartoov B. The chance of having a healthy normal child following intracytoplasmic morphologicallyselected sperm injection (IMSI) treatment is higher compared to conventional IVF-ICSI treatment. Fertil Steril. 2007;88:S20.

13. Ai L, Liu SY, Huang J, Chen SW, Liu J, Zhong Y. Intracytoplasmic morphologically selected sperm injection of testicular sperm: clinical outcome in azoospermia patients. Zhonghua Nan Ke Xue. 2010;16:826-9.

14. Oliveira JB, Massaro FC, Mauri AL, Petersen CG, Nicoletti AP, Baruffi RL, et al. Motile sperm organelle morphology examination is stricter than Tygerberg criteria. Reprod Biomed Online. 2009;18:320-6.

15. Marci R, Murisier F, Lo Monte G, Soave I, Chanson A, Urner F, et al. Clinical outcome after IMSI procedure in an unselected infertile population: a pilot study. Reprod Health. 2013;10:1-5.

16. Borges E Jr, Setti AS, Vingris L, Figueira Rde C, Braga DP, Iaconelli A Jr. Intracytoplasmic morphologically selected sperm injection outcomes: the role of sperm preparation techniques. J Assist Reprod Genet. 2013;30(6):849-54.

17. Oliveira JB, Cavagna M, Petersen CG, Mauri AL, Massaro FC, Silva LF, et al. Pregnancy outcomes in women with repeated implantation failures after intracytoplasmic morphologically selected sperm injection (IMSI). Reprod Biol Endocrinol. 2011;9:17.

18. Vanderzwalmen $\mathrm{P}$, Hiemer A, Rubner P, Bach M, Neyer A, Stecher A, et al. Blastocyst development after sperm selection at high magnification is associated with size and number of nuclear vacuoles. Reprod Biomed Online. 2008;17:617-27.

19. Qian YL, Ye YH, Xu CM, Jin F, Huang HF. Accuracy of a combined score of zygote and embryo morphology for selecting the best embryos for IVF. J Zhejiang Univ Sci B. 2008;9(8):649-5.

20. Hardarson T, Van Landuyt L, Jones G. The blastocyst. Hum Reprod. 2012;27(Suppl 1):i72-91.

21. Garolla A, Fortini D, Menegazzo M, De Toni L, Nicoletti V, Moretti A, et al. Highpower microscopy for selecting spermatozoa for ICSI by physiological status. Reprod Biomed Online. 2008;17:610-6.

22. Teixeira DM, Barbosa MA, Ferriani RA, Navarro PA, Raine-Fenning N, Nastri CO, et al. Regular (ICSI) versus ultra-high magnification (IMSI) sperm selection for assisted reproduction. Cochrane Database Syst Rev. 2013;7:1-40.

23. Setti AS, Figueira Rde C, Braga DP, Iaconelli A Jr, Borges E Jr. Intracytoplasmic morphologically selected sperm injection benefits for patients with oligoasthenozoospermia according to the 2010 World Health Organization reference values. Fertil Steril. 2011;95:2711-4.

24. Knez K, Zorn B, Tomazevic T, Vrtacnik-Bokal E, Virant-Klun I. The IMSI procedure improves poor embryo development in the same infertile couples with poor semen quality: a comparative prospective randomized study. Reprod Biol Endocrinol. 2011;9:123.

25. Kim HJ, Yoon HJ, Jang JM, Oh HS, Lee YJ, Lee $\mathrm{WD}$, et al. Comparison between intracytoplasmic sperm injection and intracytoplasmic morphologically selected sperm injection in oligoastheno-teratozoospermia patients. Clin Exp Reprod Med. 2014;41(1):9-14.

Cite this article as: Orief YI, Elabd MM, Said T, Abn Jad Ahmed NA. Comparative study between intracytoplasmic morphologically selected sperm injection versus intracytoplasmic sperm injection in patients with severe male factor infertility and repeated intra cytoplasmic sperm injection failure. Int J Reprod Contracept Obstet Gynecol 2016;5:1102-7. 